\title{
Student Worksheets Development Using Reflective Learning Based on Ethnomatematics Statistics for Students
}

\author{
Misdalina $^{1 *}$, Rohana $^{1}$ \\ ${ }^{1}$ Universitas PGRI, Palembang, Indonesia \\ ${ }^{*}$ Corresponding author. Email: rohana@univpgri-palembang.ac.id
}

\begin{abstract}
The interpretation of statistics is not easy for students to understand. A number of students have trouble learning statistics. This is due to the fact that most of the statistical books in circulation are abstract. It is therefore important to progress in students through the learning process by providing experience, reflection and action. Ethnomathematicalbased Reflective Learning is one of the lessons that can train thinking skills through the study of cultural values. The research objective was to generate Student Worksheets using ethnomatematics reflective learning based on statistical material that is true and realistic for students. This analysis approach is focused on methods of development research. Student Worksheets is validated by specialist lecturers in mathematics education and peer lecturers via a questionnaire. The practicality of the Student Worksheets was evaluated on the basis of a questionnaire and the results of student work. The results have shown that Student Worksheets is valid and realistic.
\end{abstract}

Keywords: Student Worksheets Development, Reflective Learning, Ethnomatematics Statistics

\section{INTRODUCTION}

The interpretation of statistics is not easy for students to understand. According to Chan \& Ismail, many students find it difficult to understand statistics [1]. This is due to the fact that most of the statistical books in circulation are abstract. It is therefore important to grow students through the learning process by providing experience, reflection and action to enhance their thought skills.

According to Dasari, students' thinking skills can be learned, particularly statistical material with a new paradigm, that is, teaching students not only how to make routine calculations that are full of different kinds of formulas, but that are not followed by understanding and interpreting what has been done [2]. In other words, according to Chan, Ismail \& Sumintono, the current statistical learning paradigm is that lecturers should start directing students to think statistically rather than concentrating on equations, procedures and skills, so that the teaching of statistics shifts from procedural to conceptual understanding [3].

Reflective learning is learning that includes reflective thought in the process. Reflection in the sense of learning is formulated by Boud et al [4][5] is an intellectual and affective process that involves learners to discuss their experiences in order to gain new understandings and appreciations. Zeichner and Liston argued that the idea of reflective learning is a way of improving skilled teaching skills [6]. In addition, reflective learning has been shown to enhance student mathematical skills [7].

The theory of reflective thought through reflective learning has three main elements: experience, reflection and action. These three components can be well implemented such that the pre-learning element, namely the context and post-learning element, is used, namely assessment.

One of the reflective learning models formulated by the International Center for Jesuit Education (ICAJE) is the Ignatian Pedagogy Paradigm [5]. This model of reflective learning based on the Ignatian Pedagogy Framework has been extended to Jesuit schools around the world [8]. According to Drost, the principle of reflective thought through reflective learning has three main elements: experience, reflection and action [5]. As you can see in Figure 1. 


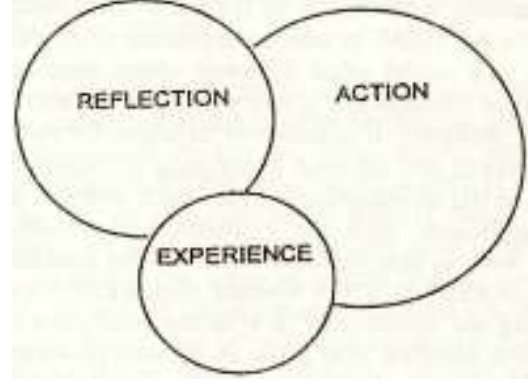

Figure 1. Ignatian Paradigm [8]

In order to properly apply these three elements, a pre-learning element is required, namely the context and the post-learning element, namely the evaluation. Thus, in its complete implementation, reflective learning is systematically implemented through five stages of reflective learning, namely: 1) context; 2) experience; 3 ) reflection; 4) action; and 5) assessment.

Introduction of meaning (context) may be achieved by the instructor at the time of perception, by connecting the material being learned to real world circumstances, and by enabling students to make correlations between their knowledge and its application in daily life. The purpose of the presentation of experience to help students use their cognitive and emotional aspects simultaneously. In addition, the Reflection Stage attempts to offer students the opportunity to use memory, comprehension, imagination and emotions and to be able to find a relationship between these items in order to capture the basic meanings and values of what they have learned. Action is the development of attitudes and behaviors exhibited by students on the basis of the experience that has been reflected. The goal of this phase of action is to train students to focus on their experiences so that they can choose the right attitude and manifest it in their behaviour. Evaluation is a step towards exploring the degree to which students have accomplished the production of cognitive and emotional aspects. Evaluation is not only an exam, but also needs to be achieved by offering peer-reviewed articles for students to document and comment on their learning experiences.

Based on the above definition, the creation of Student Worksheets using reflective learning based on ethno-mathematics is very important. The goal of this research is to generate Student Worksheets based on ethnomatematics reflective learning that is true and realistic for students.

\section{METHODS}

This study design is research and development [12]. Data collection techniques by questionnaires given to expert lecturers and peer lecturers in mathematics education. The trial was performed for students in Semester 3 of the 2020/2021 Academic Year. Data processing methods by way of validation tests of practicality. The Student Worksheets that are established shall be considered to have good validity and practicality if the minimum requirements achieved are true and practical.

\section{RESULTS AND DISCUSSION}

The creation of learning resources in the form of Student Worksheets research is limited to five phases, namely: (1) research and collection of knowledge, with needs analysis tailored to the statistical material for students that can be produced in a cultural context, paying attention to research findings relevant to ethnomatematics statistical material, and a literature review on the underlying theory of reflective learning; (2) planning, planning for reflective learning items focused on ethno-mathematics, via culture in South Sumatra, which is suitable for use as contextual in statistical content. The ethos of the Ngobeng culture is not maintained by today's society. The Ngobeng tradition is the local culture of South Sumatra. According to Fitriah, this tradition is an assimilation to the Islamic tradition, that is, to eat with one hand while sitting cross-legged according to the prophet Muhammad SAW [13]. The Ngobeng Tradition is carried out by officers standing in line to offer dishes using trays from one person to the next so that they arrive at the alms case. A pan is a tool made of rectangular wood. Food is served in plates and bowls, each plate or bowl containing three servings. According to Susanti et al [14], the food served is side dishes and pulur (which consists of vegetables, chili sauce and fruit) for one of the dishes in the tub. The number of side dishes and pulp is four plates each. In addition, rice is served in a cylindrical pan in the center of Ngobeng. One of the dishes of the Ngobeng Tradition is for 8 people in a single bowl. Typically, those who eat at a meal are grouped together with men or women, or by elders, or young people, or young women, or children. Before you eat, there are officers who walk around giving teapots and hand wash basins. Over time, however, it changed by serving three bowls together with a water-filled teapot for hand washing. How to serve dishes in one place for 8 people and each serving plate for 3 people with the form of side dishes and pulur, as well as rice covered with pan, then this Ngobeng tradition can be used as a cultural context to teach the concept of data centering size. The content being produced is the mean, mode, and median for single data and group data. The relational Ngobeng tradition has become a problem in statistical material; (3) preliminary creation of the product, the design of the ethnomamatics-based Student Worksheets (hypothetical design) referring to reflective learning, with the cultural context of the Ngobeng tradition; (4) 
main field testing, field design testing involves professional and peer testing. The parties involved in the research were lecturers as two Mathematics Education experts and colleagues to determine the validity of the product; and (5) main product revision, selective test to a group of students in the 3rd semester (three) of the 2020/2021 Academic Year to see the practicality of the product.

The results of Student Worksheets development using ethno-mathematics-based reflective learning are as follows: 1) the prototype describes the identity of the Student Worksheets by showing the curriculum, the semester 3 students, the material details, the learning outcomes of the course and the learning objectives; and 2) the prototype demonstrates ethnomathematics based on an interpretation of the cultural context used, namely the Ngobeng tradition. Tradition of serving food at an alms event by serving in groups of 8 people per 1 plate. In addition, there are 4 plates for 3 portions per person in one bowl. Since it takes one dish for 8 people, it takes three servings for one dish. For groups of 3 portions/person, prepare 3 bowls of hand washing.

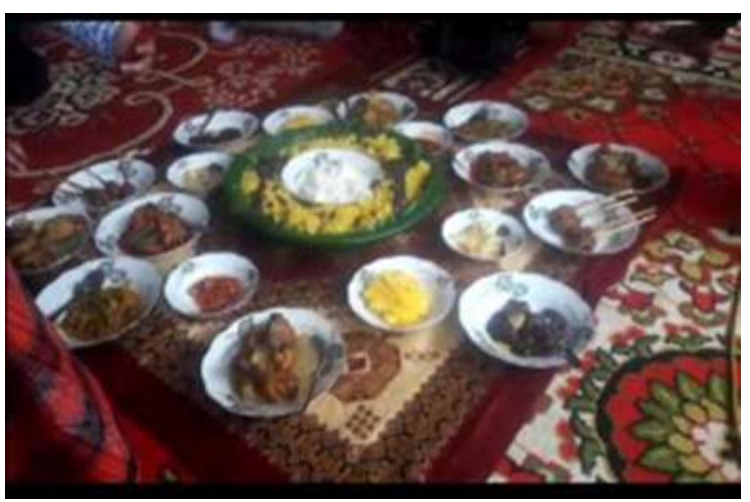

Figure 2. Ngobeng Tradition [4]

The problems raised in the sense of Ngobeng with the goal of helping students to understand the traditional Ngobeng culture and to be able to complete each activity on the statistical materials that exist in Student Worksheets.

The results of Student Worksheets Prototype validation using ethno-mathematics based Reflective learning based on material viability aspects, presentation feasibility, character education, reasoning skills and reflective learning by experts and peers can be found in Table 1.
Table 1. Expert and Peer Validation

\begin{tabular}{|c|l|c|c|}
\hline No & \multicolumn{1}{|c|}{ Aspect } & Average & Category \\
\hline 1 & Content eligibility & 3,7 & very valid \\
\hline 2 & Serving eligibility & 3,7 & very valid \\
\hline 3 & Character building & 3,6 & very valid \\
\hline 4 & Reasoning ability & 4 & very valid \\
\hline 5 & Reflective Learning & 3 & Valid \\
\hline & total & 18,4 & \\
\hline & Average & 3,68 & very valid \\
\hline
\end{tabular}

The findings of the expert validation shall be categorized as legitimate with a notice deserving of revision. In addition, the Student Worksheets was restored and became the second prototype.

The second prototype was then tested in small groups to assess the practicality of the Student Worksheets Table 2. Shows the outcome of the trial on practicality.

Table 2. Practicality of Student Worksheets Prototypes

\begin{tabular}{|l|l|l|l|}
\hline No & Aspect & Average & Category \\
\hline 1 & Display & 3,94 & Very practical \\
\hline 2 & Presentation & 3,4 & Practical \\
\hline 3 & Benefits & 3,8 & Very practical \\
\hline & total & 11,16 & \\
\hline & Average & 3,72 & Very practical \\
\hline
\end{tabular}

The results of the survey given to the student are in the realistic category. The improvement in Student Worksheets becomes the 3rd prototype, by revising the initial meaning by additional captions that clarify the many plates and bowls in dishes using the Ngobeng tradition.

The results showed that the results of the development of learning tools in the form of Student Worksheets using Ethnomatics-based Reflective Learning were considered to be relevant categories. Ethnomatematics-based Student Worksheets can be used by students. The results of research on the production of ethnomatematic-based Student Worksheets tools are also reinforced by the research findings that cultural and Islamic values can be incorporated into several statistical learning themes [16].

Furthermore, the problems raised in the sense of the Ngobeng Tradition lead students first to explain the culture of the dish by connecting the awareness and attitudes they have. In addition, to focus on and take action as if they had been engaged in the Ngobeng Tradition's work to solve the problems posed. Centered on the understanding of daily life and at the same time learning the culture of South Sumatra. This is consistent 
with the context, knowledge, reflection, intervention and assessment of reflective learning [5]. In addition, the idea of reflective learning is a way of improving the professional skills of teachers [6].

The practicality of the Student Worksheets equipment is then included in the practical category. Students may use Student Worksheets and are interested in the problems posed in the context of the Ngobeng Tradition. This ethnomatically based learning motivates students to study. This supports research that the established student workbook receives a positive response from students by demonstrating encouragement to learn mathematics because there is a cultural aspect in it [17].

\section{CONCLUSION}

Based on the results of the analysis, it can be concluded that the results of the development of the Student Worksheets using ethnomathematical reflective learning to enhance statistical reasoning skills and student character are true and realistic. In addition, this study can be continued in further research to see the possible effects of the existing prototype.

\section{AUTHORS' CONTRIBUTION}

Misdalina: designed and performed experiments and analysed data. Rohana: Performed analyses and supervised the research and co-wrote the paper.

\section{ACKNOWLEDGMENTS}

We would like to express our special thanks and appreciation to the Rector of the University of PGRI, who have assisted us in this wonderful project. This project was funded by a research grant from the University of PGRI. Secondly, we would also like to thank our friends at the University of PGRI who have supported us a great deal in finalizing this project within a short timeframe.

\section{REFERENCES}

[1] Chan, S. W. and Ismail, Z. (2013). Developing statistical reasoning assessment instrument for high school students in descriptive statistics. Procedia Social and Behavioral Sciences, vol. 116, pp. 43384343.

[2] Dasari, D. (2009). Meningkatkan Kemampuan Penalaran Statistis Mahasiswa Melalui Pembelajaran Model PACE [Improving Students' Statistical Reasoning Ability through Learning the PACE Model]. (Disertasi). Bandung: Sekolah Pascasarjana Universitas Pendidikan Indonesia.
[3] Chan, S. W., Ismail, Z., \& Sumintono, B. (2016). A Framework for Assessing High School Students' Statistical Reasoning. Plous ONE, vol. 11, no. 11.

[4] Kurnia, I. (2006). Pengembangan Model Pembelajaran untuk Meningkatkan Kemampuan Reflektif Mahasiswa S1-PGSD pada Mata Kuliah Penelitian Tindakan Kelas [Learning Model Development to Improve Reflective Ability of S1PGSD Students in Classroom Action Research Courses]. Disertasi Pengembangan Kurikulum SPS. Bandung: UPI.

[5] Sirajuddin. (2009). Model Pembelajaran Reflektif: Suatu Model Belajar Berbasis Pengalaman [Reflective Learning Model: An Experience Based Learning Model]. Didaktika Jurnal Kependidikan, vol. 4, no. 2, pp. 189-200.

[6] Radulescu, C. (2013). Reinventing Reflective Learning Methods in Teacher Education. Procedia - Social and Behavioral Sciences, vol. 78, pp. 1115.

[7] Rohana. (2015). Enhancing Prospective Teachers' Character through Reflective Learning. International Journal of Educations and Research, vol. 3, no. 7, pp. 129-140.

[8] ICAJE. (1993). Ignatian Pedagogy: A Practical Approach, Rome: http://www.rockhurst. edu/media/filer_private/uploads/ignatian_pedagogy _apractical_approach.pdf

[9] Misdalina, Zulkardi \& Purwoko. (2009). Pengembangan Materi Integral Untuk Sekolah Menengah Atas (SMA) Menggunakan Pendekatan Pendidikan Matematika Realistik Indonesia (PMRI) di Palembang [Integral Material Development for Senior High Schools (SMA) Using the Indonesian Realistic Mathematics Education Approach (PMRI) in Palembang]. Jurnal Pendidikan Matematika, vol. 3, no. 1, pp. 61-74.

[10] D'ambrosio, U. (1985). Ethnomathematics and its place in the history and pedagogy of mathematics. For the Learning of Mathematics, vol. 5, pp. 44-48.

[11] Abdullah, I. H. (2012). Peningkatan Kemampuan Pemahaman Matematis dan Representasi Matematis Siswa Siswa SMP melalui Pembelajaran Kontekstual Berbasis Soft Skills [Improved Mathematical Comprehension Ability and Mathematical Representation of Junior High School Students through Contextual Learning Based on Soft Skills]. (Disertasi), Bandung: Sekolah Pascasarjana, Universitas Pendidikan Indonesia. 
[12] W. B. \&. Gall, M. D. (1987). Educational Reaserch: An Introduction [Educational Reaserch: An Introduction]. London: London: Longman, Inc.

[13] Fitriah. (2019). Nilai Kearifan Lokal dalam Tradisi "Ngobeng"; di Desa Sri Bandung Kecamatan Tanjung Batu Kabupaten Ogan Ilir [The Value of Local Wisdom in the "Ngobeng" Tradition; in Sri Bandung Village, Tanjung Batu District, Ogan Ilir Regency]. Tamaddun: Jurnal Kebudayaan dan Sastra Islam, 19(2), pp. 39-49.

[14] Susanti, H., Mita, A., \& Arief R. C. (2019). Ngobeng dan Kambangan: Warisan Budaya yang Mulai Tergerus Arus Globalisasi [Ngobeng and Kambangan: Cultural Heritage that has begun to be eroded by the flow of globalization]. in Seminar Nasional Sejarah IV, Palembang.

[15] Gumai, S. (2019). Pemkot Palembang Ajarkan Kaum Millenial Cara "Ngidang" di Gedung Museum SMB II [The City Government of Palembang Teaches Millennials How to "Perform" at the Museum Building SMB II]. 26 Nopember 2019. [Online]. Available: https://sumateranews.co.id/pemkot-palembangajarkan-kaum-millenial-cara-ngidang-di-gedungmuseum-smb-ii/.

[16] Idris, K. (2019). Literasi Statistik Berbasis Konteks Budaya dan Keislaman: Perspektif Dosen dan Mahasiswa PTKI [Statistical Literacy Based on Cultural and Islamic Contexts: The Perspective of PTKI Lecturers and Students] in Seminar Nasional Integrasi Matematika dan Nilai Islami 3 (1), Malang.

[17] Disnawati, H. N. S. (2019). Pengembangan Lembar Kerja Siswa Berbasis Etnomatematika Tenun Timor pada Materi Pola Bilangan [Development of Ethnomatic Timor WeavingBased Student Worksheets on Number Patterns]. Jurnal Elemen, vol. 5, no. 1, pp. 64-79. 